\title{
Control of epibenthic ciliate communities by grazers and nutrients
}

\author{
Stephen A. Wickham ${ }^{1,3, *}$, Simone Nagel $^{1}$, Helmut Hillebrand ${ }^{2,4}$ \\ ${ }^{1}$ Zoological Institute, University of Cologne, Weyertal 119, 50923 Cologne, Germany \\ ${ }^{2}$ Erken Laboratory, Department of Limnology Evolutionary Biology Centre, University of Uppsala, Norr Malma 4300, \\ 76173 Norrtälje, Sweden \\ ${ }^{3}$ Present address: Department of Organismal Biology, University of Salzburg, Hellbrunnerstr. 34, 5020 Salzburg, Austria \\ ${ }^{4}$ Present address: Institute for Botany, University of Cologne, Gyrhofstrasse 15, 50931 Cologne, Germany
}

\begin{abstract}
Four in situ experiments were conducted to examine the potential top-down and bottom-up control of epibenthic ciliate communities. The experiments were run in the littoral of Lake Erken and at a brackish water site on the island of Väddö on the Baltic coast of Sweden, during the spring of 2000. The experimental manipulations were the presence/absence of the natural macrozoobenthos grazer community, cross-classified with the presence/absence of additional nutrients. Epibenthic ciliates responded to both manipulation of grazers and resources, but the response was group specific. Total ciliate abundance decreased when macrozoobenthos (largely chironomids, gastropods, trichopteran larvae, isopods and amphipods) were removed, thus excluding a direct predation effect of the macrozoobenthos community on ciliates. Total ciliate biomass, but not abundance, tended to increase in the presence of additional nutrients; an effect weakly dependent on season and site. The disparity between effects of nutrients on biomass and abundance was due to effects on heterotrichs, a group of large but relatively rare algivorous ciliates. The manipulations altered the ciliate community composition, and between lakes there were differences in species richness and diversity and experiments. However, neither the removal of macrozoobenthos nor the addition of nutrients changed species richness or diversity. This runs counter to work with other taxonomic groups, which shows maximal diversity at an intermediate level of resources or predation. This can only be partially explained by the lack of direct predation effects and the open nature of the experimental system.
\end{abstract}

KEY WORDS: Benthic $\cdot$ Ciliate $\cdot$ Top-down $\cdot$ Bottom-up $\cdot$ Diversity

Resale or republication not permitted without written consent of the publisher

\section{INTRODUCTION}

While the role of ciliates in the pelagial is relatively well understood, the control mechanisms for benthic ciliates are still largely unknown. Elevated levels of macrozoobenthos, such as oligochaetes, snails and mayfly nymphs, are known to result in reduced ciliate abundance (Taylor 1980, McCormick 1991). There are also reports of meiobenthos being able to reduce ciliate biomass, with ostracods, nematodes, rotifers and copepods having a negative relationship with ciliate abundance (McCormick \& Cairns 1991, Bott \& Borchardt 1999, Wickham et al. 2000). There are, however, few grazing or ingestion rate measurements for either macrozoobenthos or meiofauna on ciliates. As a result, it is not clear whether the observed negative correlation between macrozoobenthos or meiofauna biomass and ciliate biomass is due to direct predation, or due to indirect effects such as competition for shared resources. Benthic ciliates range in size from 20 to $30 \mu \mathrm{m}$ for small hypotrichs and scuticociliates, to over $1 \mathrm{~mm}$ for large heterotrichs and karyorelictids. As a result, even if the main interaction between ciliates and macrozoobenthos or meiofauna is direct predation, the strength of the interaction is likely to be dependent on the species composition of the predator and prey community. No one macrozoobenthic or meiofaunal species is likely to be able to graze the full range of the benthic or epiben- 
thic ciliate community, leaving open the possibility that increased predation levels may have a greater effect on ciliate species composition than on total ciliate biomass.

The importance of resource or bottom-up control for benthic ciliates is another open question. Benthic ciliates have feeding niches that range from bacteria or small algae to large diatoms or filamentous algae and even carnivory on other ciliates and micrometazoa (Bott \& Kaplan 1990, McCormick 1991, Epstein 1997, Foissner et al. 1999). To our knowledge, there have been no studies on the role of nutrient levels in determining benthic or epibenthic ciliate biomass. It is known that increased nutrient levels result in higher macrozoobenthos abundance, although it is not clear how much of this is due to higher growth resulting from higher quantity or quality of periphyton, and how much is simply due to immigration in open experimental systems (Hill et al. 1992, Frost \& Elser 2002, Stelzer \& Lamberti 2002). It is possible that increased nutrient supply would not affect all potential prey for ciliates equally, and as a result, it is unclear whether raising nutrient levels would generally raise ciliate biomass, or whether only a few groups would benefit. A further possibility is that increased nutrients would increase ciliate growth rates, but this extra production would be transferred to higher trophic levels, reducing or eliminating any increase in ciliate biomass. This phenomenon has been observed for marine meiofauna grazing on algae (Montagna et al. 1995).

To address these questions, we conducted a series of in situ experiments where the presence and absence of supplemental inorganic nutrients and of the natural macrozoobenthos community were manipulated. The experiments were conducted not only to address questions on the role and control of epibenthic ciliates, but of the entire epibenthic community, from bacteria to macrozoobenthos. The results of the experiments for bacteria, algae and meiofauna as well as total ciliate biomass are reported in Hillebrand \& Kahlert (2001) and Hillebrand et al. (2002). Here, we report on the taxon-specific responses of ciliate abundance and biomass as well as the effects of the experimental manipulations on ciliate species diversity and richness. The ciliate samples were counted with a technique that allows identification to the genus and sometimes species level, permitting much more detailed results than simply total ciliate abundance or biomass. The hypotheses tested with regard to the ciliates were that (1) macrozoobenthos would have direct predation effects on ciliates, (2) the addition of inorganic nutrients would indirectly enhance ciliate biomass, and (3) the 2 effects would be independent of one another. We further hypothesized that predator and nutrient effects would be species specific, and that ciliate diversity and species richness would be higher in the presence of predators or enhanced nutrients.

\section{MATERIALS AND METHODS}

The experiments were carried out in the littoral of a freshwater and a brackish water site in Sweden. The freshwater site was located in Lake Erken, at the Erken Field Laboratory $\left(59^{\circ} 50^{\prime} \mathrm{N}, 18^{\circ} 37^{\prime} \mathrm{E}\right)$. Lake Erken is mesotrophic (mean chlorophyll [chl a] $5.6 \mu \mathrm{g} \mathrm{l}^{-1}$, mean total phosphorus [TP] $0.94 \mu \mathrm{mol} \mathrm{l}^{-1}$ ) with a mean depth of $9 \mathrm{~m}$ and is ice-free from April to December. The second site was located in an embayment on Väddö, an island on the Swedish Baltic coast (59 $56^{\prime} \mathrm{N}, 18^{\circ} 55^{\prime} \mathrm{E}$ ). The site is brackish (5.5 psu) and of similar productivity as Lake Erken (mean chl a $7.0 \mu \mathrm{g} \mathrm{l}^{-1}$, mean TP 0.77 $\mu \mathrm{mol} \mathrm{l}{ }^{-1}$; data from the Erken Laboratory monitoring program). (See Hillebrand \& Kahlert (2001) and Hillebrand et al. (2002) for more details on the experimental sites.) At both sites, the experimental substrates (ceramic tiles, $5 \times 5 \mathrm{~cm}$ ) were incubated at 70 to $90 \mathrm{~cm}$ depth. The tiles were placed on concrete paving stones and incubated for a minimum of 3 mo prior to the experiments in order to allow a natural periphyton community to develop. The macroinvertebrate community was composed of chironomid larvae (numerically dominant at both sites), gastropods (Theoduxus fluviatilis at both sites as well as Hydrobia spp. at Väddö), trichopteran larvae (Erken), and at Väddö, isopods and amphipods (Hillebrand \& Kahlert 2001).

The experiments were run twice, directly after iceout on Lake Erken for 38 d (17 April to 24 May 2000) and in late spring for 28 d (24 May to 19 June 2000). Experiments in Erken and Väddö were started on subsequent days, and were run in parallel. The experimental design was the cross-classified manipulation of 2 levels of nutrients and 3 levels of grazers, with 4 replicates per treatment combination. An experimental unit was a paving stone with multiple tiles on it, all of which were subject to the same grazer or nutrient manipulation. The paving stones were placed at least $50 \mathrm{~cm}$ from one another to ensure that experimental effects from one experimental unit would not affect another. Treatment assignments to the paving stones was done with a random number generator. Nutrients were added to half the tiles in the form of $30 \mathrm{~g}$ of a granular slow-release NPK fertilizer (Plantacote $^{\mathrm{TM}}$ Depot 6M, Urania Agrochem) in porous plastic containers next to the nutrient-enriched treatments (abbreviated as NUT; treatments with only ambient nutrient level: AMB). Previous work has shown this design to release nutrients for at least $6 \mathrm{wk}$ (Worm et al. 2000). Macroinvertebrate grazers were excluded from a third of the treatments (ABS) by attaching $15 \times$ $15 \times 15 \mathrm{~cm}$ cages with a $1 \mathrm{~mm}$ clear polyethylene mesh to the paving stones on which the tiles were resting. Treatments with grazers present (PRES) had cages open on 2 sides to allow the entry and exit of macro- 
invertebrates, but otherwise mimic the effects of the ABS treatment in terms of any cage effects independent of the presence or absence of macroinvertebrates. The meshes were replaced every 5 to $10 \mathrm{~d}$ during the experiment to prevent the build-up of algae on the mesh. To test for effects of the cages independent of the exclusion of macroinvertebrates, a third treatment level (CON), without a cage of any sort, was used as a control for cage artifacts.

At the end of an experiment, 2 tiles per replicate (paving stone) were harvested for ciliates, meiofauna and algae. The tiles were gently and immediately placed in plastic bags with $0.2 \mu \mathrm{m}$ filtered water, in order to minimally disturb the attached and interstitial communities. Tiles were stored at $4^{\circ} \mathrm{C}$ in the dark until further processing. The tiles were then scraped with razor blades into a defined volume of water (usually 100 to $200 \mathrm{ml}$, pooling the 2 tiles per replicate) and algal clumps were broken up. A $50 \mathrm{ml}$ subsample was then taken and fixed in 5\% (end concentration) Bouin's fixative. A further subsample was used for live observation of ciliates to aid in their identification. Ciliates were counted using the Quantiative Protargol Stain (QPS), which stains cilia, ciliary basal bodies and nuclei (Montagnes \& Lynn 1987, Skibbe 1994). Between 0.5 and $3 \mathrm{ml}$ of the samples were gently ( $<5 \mathrm{~mm} \mathrm{Hg}$ ) filtered onto $1.2 \mu \mathrm{m}$ pore-size cellulose nitrate filters, and after staining, the filter was counted in its entirety at 200× magnification, using 400 and $1000 \times$ for identification. A minimum of 40 ciliates was counted per filter. The volume filtered was chosen to maximize the number of ciliates on a filter without the algal density being so high as to mask the ciliates. With the QPS method, ciliates could be simultaneously counted and be identified usually to genus and occasionally to species. Kahl (1930-1935), Carey (1992) and Foissner et al. (1999) were used to identify ciliates. Cells were also measured during counting, and their biovolume was estimated using common geometric formulas. Biovolume was converted into biomass assuming 0.14 pg C $\mu^{-3}$ (Putt \& Stoecker 1989). Species diversity was measured using the ShannonWiener $\mathrm{H}^{\prime}$ and abundance data, and species richness as the number of species or morphotypes present. Similarity in community composition between experiments and lakes was measured using the Jaccard measure of similarity. This is measured as:

$$
C_{j}=\frac{j}{(a+b-j)}
$$

where $a$ and $b$ are the number of morphotypes in samples $\mathrm{A}$ and $\mathrm{B}$, and $j$ is the number of morphotypes found in both $\mathrm{A}$ and $\mathrm{B}$ (Magurran 1988). $C_{j}$ ranges from 0 to 1 , and is the proportion of shared morphotypes.
The statistical analysis was similar to that used by Hillebrand \& Kahlert (2001) and Hillebrand et al. (2002). The analysis was broken into 2 parts: the first to test between the CON and PRES treatments for cage artifacts, and the second excluding the CON treatment, to test the factorial model of grazer and nutrient effects with their interactions. Abundance, biomass and richness data were log-transformed prior to analysis, in order to equalize variance between treatments, but untransformed data are presented in the figures. Unlike Hillebrand \& Kahlert (2001) and Hillebrand et al. (2002), there were only 2 experiments per site analyzed for ciliates, which allowed site to be included as a factor in a single 4-way ANOVA (Macrozoobenthos $\times$ Nutrient $\times$ Site $\times$ Season) without the analysis becoming unbalanced. Because the data were tested in 4 separate analyses (abundance, biomass, diversity and species richness), the $\alpha$-level used for any one test was adjusted from 0.05 to 0.0125 . Effects with a p-value between 0.0125 and 0.025 were considered marginally significant. The effects of the experimental manipulations on the taxonomic composition of the ciliate community were examined with a log-likelihood ratio chi-square test on the biomass proportions made up by ciliate groups ( $G$ - or $G^{2}$-test; Sokal \& Rohlf 1995). For this analysis, ciliates were taxonomically grouped at the class or order level. Groups that in all treatments made up less than $2 \%$ of the total biomass were, together with unidentified ciliates, summed in the group 'Other'. All data analysis was carried out using SAS, ver. 6.12 (SAS Institute 1989).

\section{RESULTS}

Mean ciliate abundance across both season and sites was 440 ciliates $\mathrm{cm}^{-2}$, but this varied from 87 ciliates $\mathrm{cm}^{-2}$ in the Erken late spring ABS AMB treatment, to 1280 ciliates $\mathrm{cm}^{-2}$ in the Väddö late spring CON NUT treatment. Exclusion of grazers resulted in lower ciliate abundance in all experiments (Fig. 1; Grazer main effect, $\mathrm{p}<0.0001)$. Averaged across all 4 experiments, removing macrozoobenthos reduced ciliate abundance by $40 \%$, although this reduction varied from $18 \%$ in the Erken late spring experiment to $69 \%$ in the Väddö late spring experiment. There were also differences in ciliate abundance across seasons and sites, but neither of these treatments interacted with the main grazer effect (Table 1, Fig. 1). The Grazer effect was also independent of the addition of nutrients (Grazer $\times$ Nutrient interaction, $\mathrm{p}=0.114$ ).

Ciliate abundance was on average 150 ciliates $\mathrm{cm}^{-2}$ lower when the open-sided cages were present (PRES treatment), compared to treatments with no cages whatsoever (CON; Fig. 1, p = 0.0053). This effect was 


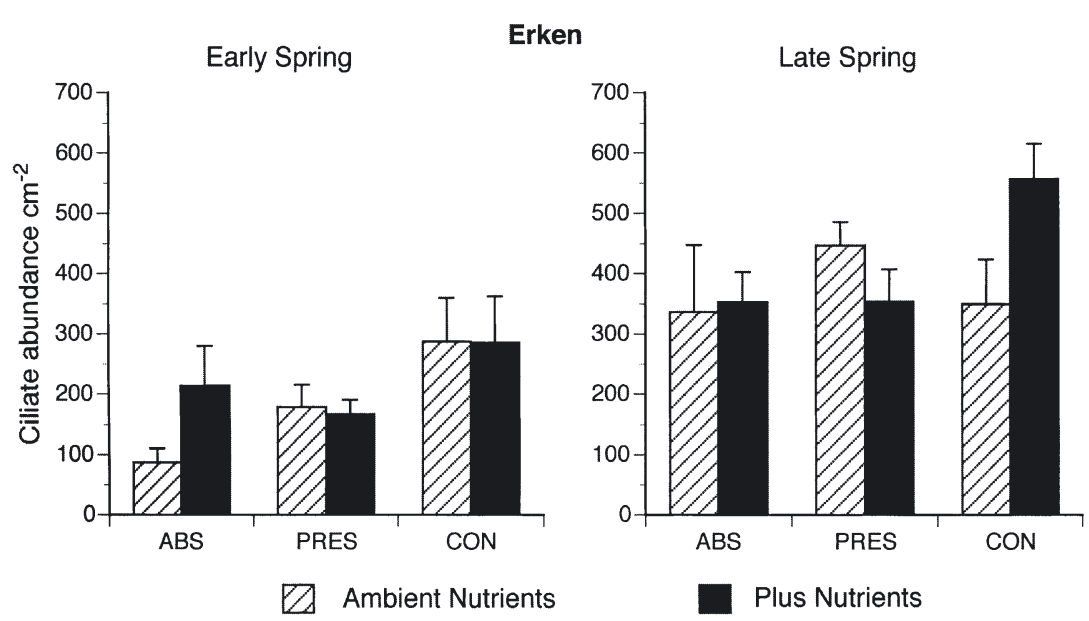

Väddö
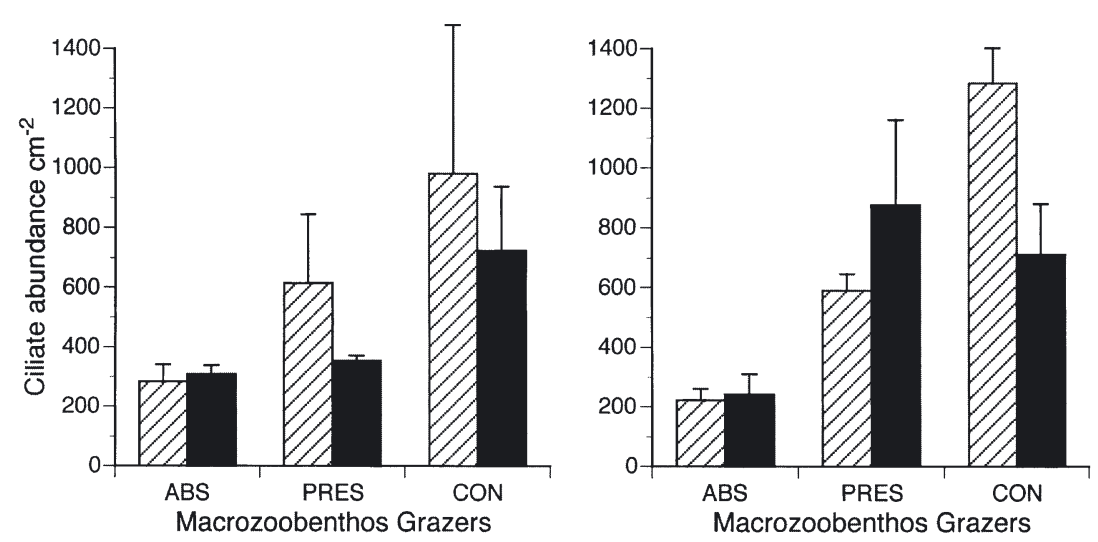

Fig. 1. Total ciliate abundance in the 4 experiments, given as cells $\mathrm{cm}^{-2}$. Solid bars are plus nutrients, striped bars are ambient nutrients (referred to as NUT and AMB in the text). ABS, PRES and CON are, respectively, the macrozoobenthos absent (macrozoobenthos excluded with a cage), macrozoobenthos present (cage present, but open on 2 sides to allow access by macrozoobenthos) and the cage-control treatments (no cage whatsoever, compared to PRES, in order to ascertain whether the cages caused artifacts independent of the presence/ absence of macrozoobenthos). Error bars are 1 SE of the means of the untransformed data, but for the statistical analyses, log-transformed data were used. Note that the abundance scale is different in the Erken and Väddö experiments

both site and season dependent, with significant Cage $\times$ Season and Cage $\times$ site Interactions $(p<0.0001$ for both, Table 1). The mean difference between PRES and CON treatments ranged from 290 ciliates $\mathrm{cm}^{-2}$ in the Väddö early spring experiment to 37 ciliates $\mathrm{cm}^{-2}$ in the Erken late spring experiment (values averaged over NUT treatments and back-transformed from logtransformed data).

In contrast with the strong grazer effect, addition of nutrients had no significant effect on ciliate abundance, either as a main effect or as an interaction with the cage effect, site or season (Table 1, Fig. 1). The lack of a significant effect from nutrients was not due to a large difference being masked by a still larger withinreplicate variance. Averaged over all experiments, there were only $10 \%$ more ciliates in treatments with, as compared to without, additional nutrients.

Mean ciliate biomass across all experiments and sites was $1.85 \mu \mathrm{g} \mathrm{C} \mathrm{cm}^{-2}$, and ranged from a high of $4.08 \mu \mathrm{g} C$ $\mathrm{cm}^{-2}$ in the Erken late spring $\mathrm{CON}$ AMB treatment to a low of $0.225 \mu \mathrm{g} C$ $\mathrm{cm}^{-2}$ in the Väddö late spring ABS AMB treatment (Fig. 2). Put into perspective, mean ciliate biomass was only $1.6 \%$ of algal biomass, but $18 \%$ of bacterial biomass and $530 \%$ of the meiofauna biomass (algal, bacterial and meiofauna data from Hillebrand et al. 2002). As with ciliate abundance, ciliate biomass was significantly different between lakes and experiments (Table 1). The effect of the presence or absence of grazers was, however, much weaker with biomass than with abundance (Table 1, Fig. 2). The significance level of the grazer effect on biomass ( $p=$ 0.0153 ) was slightly above the critical level of 0.0125 set for the experiments, and therefore can only be considered a marginally significant trend of higher ciliate biomass with the presence of grazers. However, the magnitude of the change $(38 \%$ less biomass when macrozoobenthos were absent, averaged over all 4 experiments) was only slightly less than the $40 \%$ reduction seen in abundance.

As with ciliate abundance, the presence of cages had an effect on ciliate biomass independent of the exclusion of macrozoobenthos grazers. Unlike the effect on abundance however, ciliate biomass was significantly affected by only the 4 -way, Season $\times$ Site $\times$ Cage $\times$ Nutrient interaction (Table 1). This was due to the large difference between the AMB and NUT treatments in the Väddö early spring CON treatment that did not appear in the other experiments (Fig. 2). Generally, there was slightly more ciliate biomass in the CON, as compared to the PRES treatments, but the main cage effect was not significant (Table 1).

The overall effect of nutrients on ciliate biomass was greater than on abundance, although here too, the pvalue of the main nutrient effect $(p=0.0176)$ was slightly above the $\alpha$-level of 0.0125 . Nevertheless, there was at least a non-significant trend towards higher ciliate biomass with raised nutrient levels, with an average of $69 \%$ more ciliate biomass found when 
Table 1. p-values for the cage control analysis (with only the present and control grazer treatments) and the main analysis (without the grazer control treatment). Season is the timing of the experiments (early or late spring) and NUT is the nutrient treatment (ambient and enriched). Ciliate abundance, biomass and species richness were log-transformed prior to analysis. Because the same data were used in 4 different analyses (abundance, biomass, species richness and diversity), the critical $\alpha$-level was reduced from 0.05 to 0.0125 for any one analysis. p-levels beneath 0.0125 are marked in bold. Effects with a p-level between 0.0125 and 0.025 were considered as marginally significant trends, and are marked in italics

\begin{tabular}{|lcccc|}
\hline Factor & Abundance & Biomass & $\begin{array}{c}\text { Species } \\
\text { richness }\end{array}$ & $\begin{array}{c}\text { Species } \\
\text { diversity }\end{array}$ \\
\hline Cage control analysis & & & & \\
Cage & & & & \\
Cage $\times$ Season & $\mathbf{0 . 0 0 5 3}$ & 0.2333 & 0.2773 & 0.6987 \\
Cage $\times$ NUT & $\mathbf{0 . 0 0 0 1}$ & 0.7542 & $\mathbf{0 . 0 0 0 1}$ & $\mathbf{0 . 0 0 0 1}$ \\
Cage $\times$ Site & 0.7703 & 0.5286 & 0.5560 & 0.2688 \\
Cage $\times$ Season $\times$ NUT & $\mathbf{0 . 0 0 0 1}$ & 0.1993 & $\mathbf{0 . 0 0 0 1}$ & $\mathbf{0 . 0 0 1 4}$ \\
Cage $\times$ NUT $\times$ Site & 0.7975 & 0.3236 & 0.2337 & $\mathbf{0 . 0 0 7 4}$ \\
Cage $\times$ Season $\times$ NUT $\times$ Site & 0.1295 & 0.8057 & 0.9029 & 0.1188 \\
Main analysis & 0.1997 & $\mathbf{0 . 0 0 4 6}$ & $\mathbf{0 . 0 0 1 2}$ & $\mathbf{0 . 0 0 0 5}$ \\
Season & & & & \\
Site & $\mathbf{0 . 0 0 0 1}$ & 0.0681 & $\mathbf{0 . 0 0 0 1}$ & $\mathbf{0 . 0 0 0 1}$ \\
Grazer & $\mathbf{0 . 0 0 0 1}$ & $\mathbf{0 . 0 0 3 4}$ & $\mathbf{0 . 0 0 8 5}$ & 0.6258 \\
NUT & $\mathbf{0 . 0 0 0 1}$ & 0.0153 & 0.1376 & 0.9654 \\
Grazer $\times$ NUT & 0.3886 & 0.0176 & 0.1413 & 0.1655 \\
Season $\times$ Site & 0.1138 & 0.3023 & 0.2697 & 0.9461 \\
Grazer $\times$ Season & $\mathbf{0 . 0 0 0 7}$ & $\mathbf{0 . 0 0 0 1}$ & $\mathbf{0 . 0 0 0 1}$ & $\mathbf{0 . 0 0 0 1}$ \\
Grazer $\times$ Site & 0.1381 & 0.3904 & 0.3873 & 0.3244 \\
Grazer $\times$ Season $\times$ Site & 0.0261 & 0.1875 & 0.2887 & 0.0292 \\
NUT $\times$ Season & 0.0594 & 0.1566 & 0.7948 & 0.3059 \\
NUT $\times$ Site & 0.6340 & 0.7966 & 0.5105 & 0.2739 \\
NUT $\times$ Season $\times$ Site & 0.4761 & 0.7245 & 0.5908 & 0.3300 \\
Grazer $\times$ NUT $\times$ Season & 0.1266 & 0.0223 & 0.1909 & 0.3708 \\
Grazer $\times$ NUT $\times$ Site & 0.1547 & 0.1572 & 0.6083 & 0.9240 \\
Grazer $\times$ NUT $\times$ Season $\times$ Site & 0.2250 & 0.2347 & 0.9517 & 0.7959 \\
& 0.7200 & 0.5014 & 0.8683 & 0.4548 \\
\hline
\end{tabular}

A total of 135 ciliate species or morphotypes were found in the 4 experiments. However, in any one treatment and experiment, mean species richness was a maximum of 33 (Väddö early spring, ABS NUT treatment) and a minimum of 13 (Väddö late spring, PRES AMB treatment, Fig. 3). There was relatively little overlap in the species composition, either between season or site. Within sites, no more than $55 \%$ ( $\mathrm{J}=0.544$, Table 2$)$ of the taxa were shared between experiments, and between sites, no more than $42 \%$. The lowest taxonomic similarity was between sites for experiments conducted at different times.

Despite the differences in abundance, and to a lesser extent, biomass, due to the experimental manipulations, species richness and ShannonWiener diversity showed a very muted response (Figs. 3 \& 4). Significant differences were found between sites and seasons, but there was no consistent pattern of one site or season being more species rich or diverse (Figs. $3 \&$ 4; Lake $\times$ Experiment interaction, $\mathrm{p}<$ 0.001). Within experiments, species richness and diversity were remarkably constant, without significant effects for either grazers or nutrients, or for their interactions (Table 1). With the exception of the Väddö late spring

nutrients were added. There was also a trend towards a significant Nutrient $\times$ Season $\times$ Site interaction $(\mathrm{p}=$ 0.022 , Table 1 ). This was due to the wide variation in the nutrient effect between experiments. Adding nutrients increased ciliate biomass by less than $5 \%$ in the Väddö early spring and Erken late spring experiments, but by over $100 \%$ in the other 2 experiments (Fig. 2).

In addition to the marginally significant trend of a positive effect of nutrients on ciliate biomass, there were positive correlations between ciliates and their putative prey. Whether the correlations were significant, however, was dependent on how ciliates were measured. Ciliate abundance, dominated by the bacterivorous scuticociliates and small peritrichs, was positively correlated with bacterial biomass (Pearson's $r=0.46, p=0.0002$, both parameters log-transformed), but not with algal biomass $(r=-0.003, p=0.98)$. Conversely, ciliate biomass, dominated by algivorous heterotrichs and larger peritrichs, was positively correlated with algal biomass $(\mathrm{r}=$ $0.50, p=0.0001)$, but not with bacterial biomass $(r=0.15$, $\mathrm{p}=0.26)$. experiment, none of the treatments produced more than a 3 species difference in the species richness (Fig. 3). In Väddö in late spring, there appeared to be a trend towards higher diversity with added nutrients and with grazers present (Fig. 4), but even when this experiment was considered in isolation, the effects were not significant $(p>0.15)$. Thus, while the experimental manipulations affected the abundance and biomass of the epibenthic ciliate community, neither species richness or diversity was influenced.

Ciliate community composition was dominated by peritrich ciliates (largely Vorticella spp., Corthunia annulata and Thurikola kellicottiana) in both lakes, in both early and late spring. Peritrichs contributed a mean of $41 \%$ to the total ciliate biomass across all experiments and lakes (range over all experiments and treatments, 16 to $72 \%$, Fig. 1). Peritrichs also made up, on average, $26 \%$ of ciliate abundance, with a range of 7.3 to $63 \%$ (data not shown). The second most important group in terms of biomass were heterotrichs such as Climacostumum virens and Stentor spp. (mean bio- 


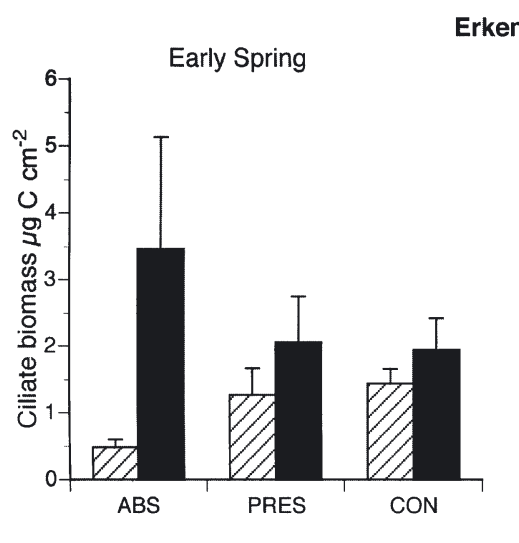

Ambient Nutrients

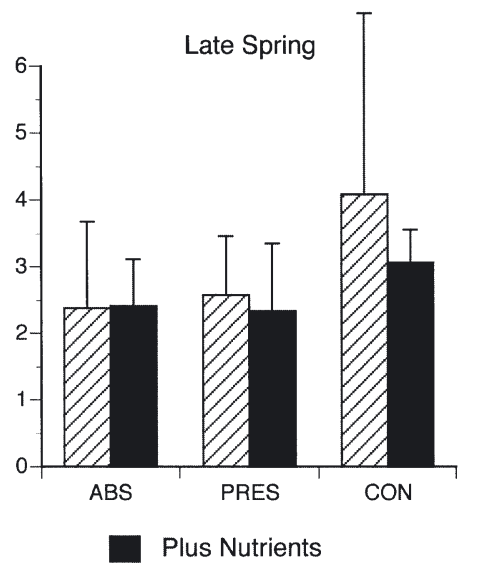

Väddö
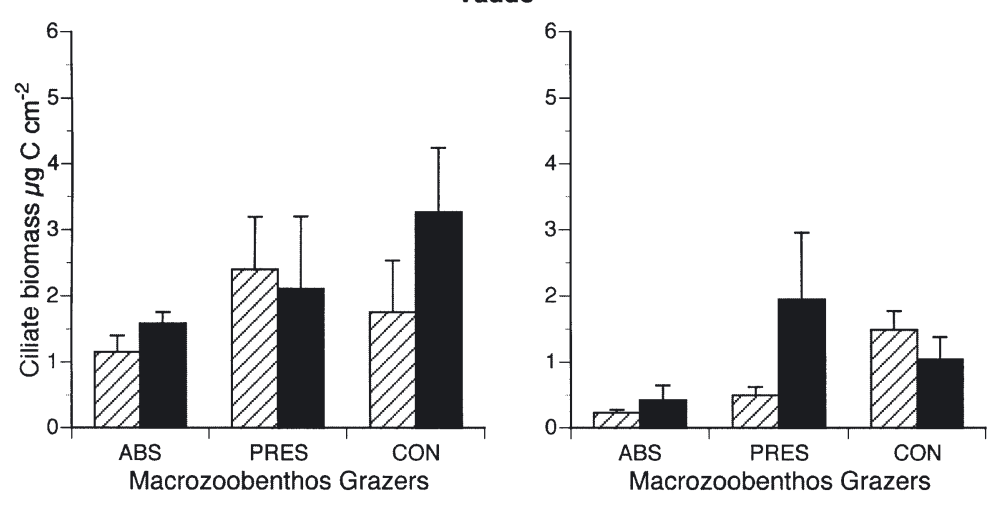

Fig. 2. Total ciliate biomass in the 4 experiments, given as $\mu \mathrm{g} \mathrm{Cm}^{-2}$. Abbreviations, symbols and error bars as in Fig. 1
The effect of grazers on community composition, however, was only significant under ambient nutrient conditions (Grazer log-likelihood chi-square test, AMB: $p=0.003$; NUT: $p=0.80$ ). A general pattern averaged over all 4 experiments was that under ambient nutrient conditions, bacterivores (Peritrichia and Scuticociliatia) increased their proportion of total ciliate biomass from $37 \%$ in the absence of macrozoobenthos to $63 \%$ in their presence. When nutrients were added, their proportion remained at $37 \%$, regardless of whether macrozoobenthos were excluded. This pattern was most evident in the Väddö early spring and Erken late spring experiments. A corollary to this pattern was that ciliates capable of ingesting large diatoms and filamentous algae (nassulids, which were grouped in 'Other', Phyllopharyngia and Heterotrichia; the group was dominated by Heterotrichia) declined when macrozoobenthos were present, but only under ambient nutrient conditions (log-likelihood chi-square test for grazers, AMB: $\mathrm{p}=0.009$; NUT: $\mathrm{p}=0.79$ ). Averaged over the 4 experiments, these groups made up $24 \%$ of total ciliate biomass in ABS AMB treatments, but only $10 \%$ in PRES AMB treatments. In NUT treatments, they made up 33 and $35 \%$ of ciliate biomass in ABS and PRES treatments, respectively. In the individual experiments, this was best exemplified in the Väddö early spring experiment (Fig. 5).

\section{DISCUSSION}

scuticociliates (eg. Plueronema spp., Glaucoma spp.; mean biomass proportion, $6.5 \%$, range 1.7 to $16 \%$, Fig. 5). The heterotrichs found in the experiments were relatively large bodied, and therefore their mean abundance contribution (5.0\%) was considerably less than their biomass contribution. Conversely, scuticociliates are relatively small (most between 20 and $30 \mu \mathrm{m}$ in length), and therefore made up a larger proportion of the total abundance than of the total biomass (mean abundance, $27 \%$, range 5.8 to $52 \%$ ).

While neither species richness nor diversity was influenced by the experimental manipulations, species composition was affected. The addition of nutrients resulted in a marginal increase from 26 to $39 \%$ averaged over the 4 experiments in the proportion of benthic ciliate algivores, (hetrotrichs, hypotrichs, stichotrichs and Phyllopharyngia; log-likelihood chi-square test for nutrients: $p=0.045$ ). A nutrient effect was most evident for heterotrichs, increasing from 18 to $32 \%$ when nutrients were added, and for the bacterivorous peritrichs, which declined from 44 to $32 \%$. The effect was particularly visible in the Erken early spring experiment (Fig. 5).
The ciliate community in these experiments was clearly influenced by macrozoobenthos grazer presence/absence and, to a lesser extent, enhanced nutrient supply. The effects were, however, taxon-specific, with a few groups responding strongly, but some not at all. Ciliate species composition varied considerably between experiments and sites, and perhaps as a result, there were large differences in the impact of the experimental manipulations between experiments.

Contrary to our expectations, the removal of macrozoobenthos reduced, rather than enhanced the biomass and, particularly, the abundance of ciliates. We had expected that the presence of macrozoobenthos would reduce ciliate abundance and biomass either through direct ingestion or through competition for shared algal resources. This has previously been shown, with elevated densities of snails, mayfly nymphs and oligochaetes reducing ciliate abundances (Taylor 1980, McCormick 1991). Conversely, an enhancement of ciliates in the presence of macrozoobenthos could be expected 

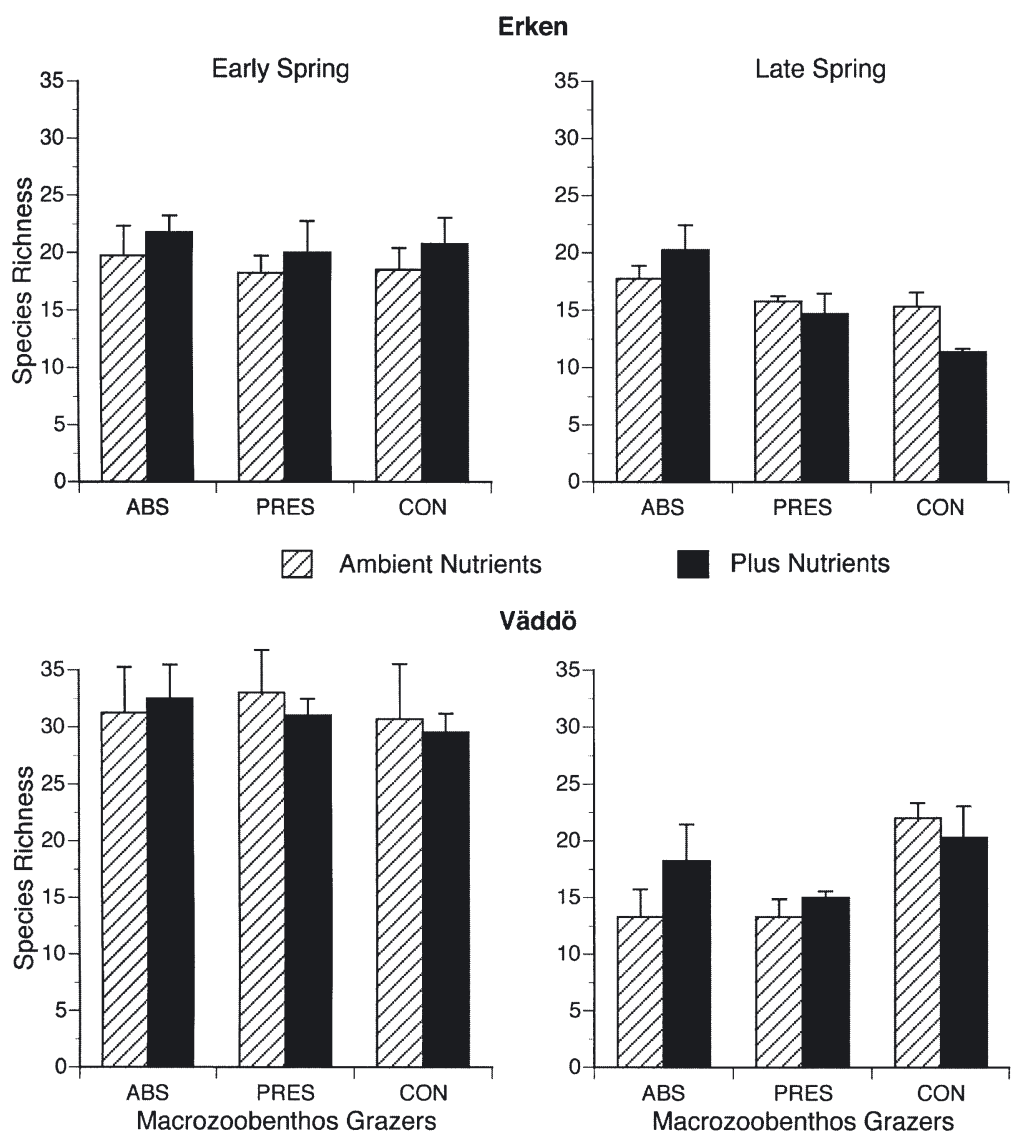

Väddö

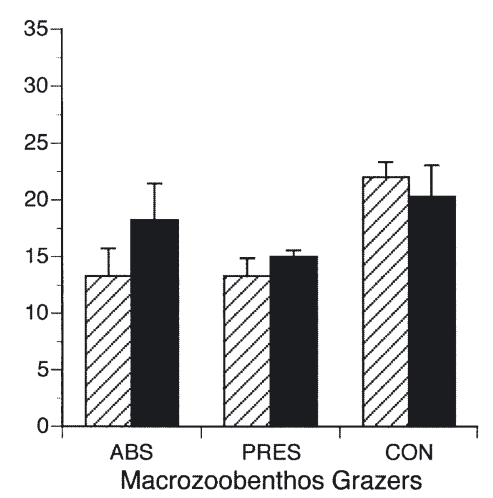

Fig. 3. Species richness (number of species) in the 4 experiments. Abbreviations, symbols and error bars as in Fig. 1

if a trophic cascade, where macrozoobenthos preyed upon an intermediate trophic level which in turn preyed upon ciliates, was taking place. While there is relatively little quantitative data, many macrozoobenthos groups are known to prey on meiofauna (reviewed in Schmid-Araya \& Schmid 2000). Meiofauna in turn are known to prey on ciliates (McCormick \& Cairns 1991, Epstein \& Gallagher 1992, Wickham et al. 2000), and could therefore serve as the intermediate trophic level. However, meiofauna and ciliates responded similarly, with reduced biomass when macrozoobenthos

Table 2. Jaccard similarity index, a measure of the proportion of shared species between the 4 experiments in Erken and Väddö. The index ranges from 0 , where no species are shared, to 1, where all species are present in both samples

\begin{tabular}{|lccc|}
\hline Expt & $\begin{array}{c}\text { Erken } \\
\text { late spring }\end{array}$ & $\begin{array}{c}\text { Väddö } \\
\text { early spring }\end{array}$ & $\begin{array}{c}\text { Väddö } \\
\text { late spring }\end{array}$ \\
\hline Erken early spring & 0.544 & 0.419 & 0.375 \\
Erken late spring & & 0.414 & 0.426 \\
Väddö early spring & & & 0.533 \\
\hline
\end{tabular}

were removed (Hillebrand et al. 2002). As a result, other indirect effects must have been responsible for the positive effect of macrozoobenthos on ciliates. It is unlikely that predacious ciliates (primarily belonging to the class Haptorida), through predation on either other ciliates or meiofauna, played a large enough role to obscure a trophic cascade, as they were never more than $5 \%$ of the total ciliate biomass (Fig. 5).

There was a general trend towards higher ciliate abundance in the cage controls (CON) compared to the PRES treatments. A plausible explanation for the observed trend is that the 2-sided cages of the PRES treatments reduced the access of macrozoobenthos in comparison to the fully cageless CON treatments, thereby reducing the indirect positive effect of macrozoobenthos on ciliates. The nature of the experiments, however, precluded the direct enumeration of macrozoobenthos.

The indirect macrozoobenthos effects on ciliates were ciliate group specific. The ciliates which benefited most from the presence of macrozoobenthos were peritrichs and scuticociliates, both of which preferentially graze the small algae and bacteria that would benefit most, and react the fastest, to nutrients liberated by macrozoobenthos grazing (Fenchel 1980, Šimek et al. 1994, 1995, Foissner et al. 1999). Under ambient nutrient conditions, these ciliates declined from 63 to $37 \%$ of total ciliate biomass (averaged over all 4 experiments) when macrozoobenthos were excluded. When nutrients were added, however, the proportion of biomass made up by peritrichs and scuticociliates remain at $37 \%$, independent of grazer presence/absence. Ciliate abundance, dominated by small peritrichs and scuticociliates, was also positively correlated with bacterial abundance. This would suggest that nutrient regeneration by macrozoobenthos was important to the ciliate-macrozoobenthos interaction. Algal C:P ratios declined when grazers were present (Hillebrand \& Kahlert 2001), indicating that nutrient regeneration (perhaps in combination with deeper light penetration into the algal mat) as a result of grazing was a component of macrozoobenthos effects on the epibenthic community.

Macrozoobenthos grazers did not reduce algae uniformly, but had their greatest impact on diatoms and filamentous algae (Hillebrand \& Kahlert 2001). The ciliates most capable of grazing these algal types (heterotrichs, nassulids and Phyllopharyngia) declined relative to other ciliate groups when macrozoobenthos 

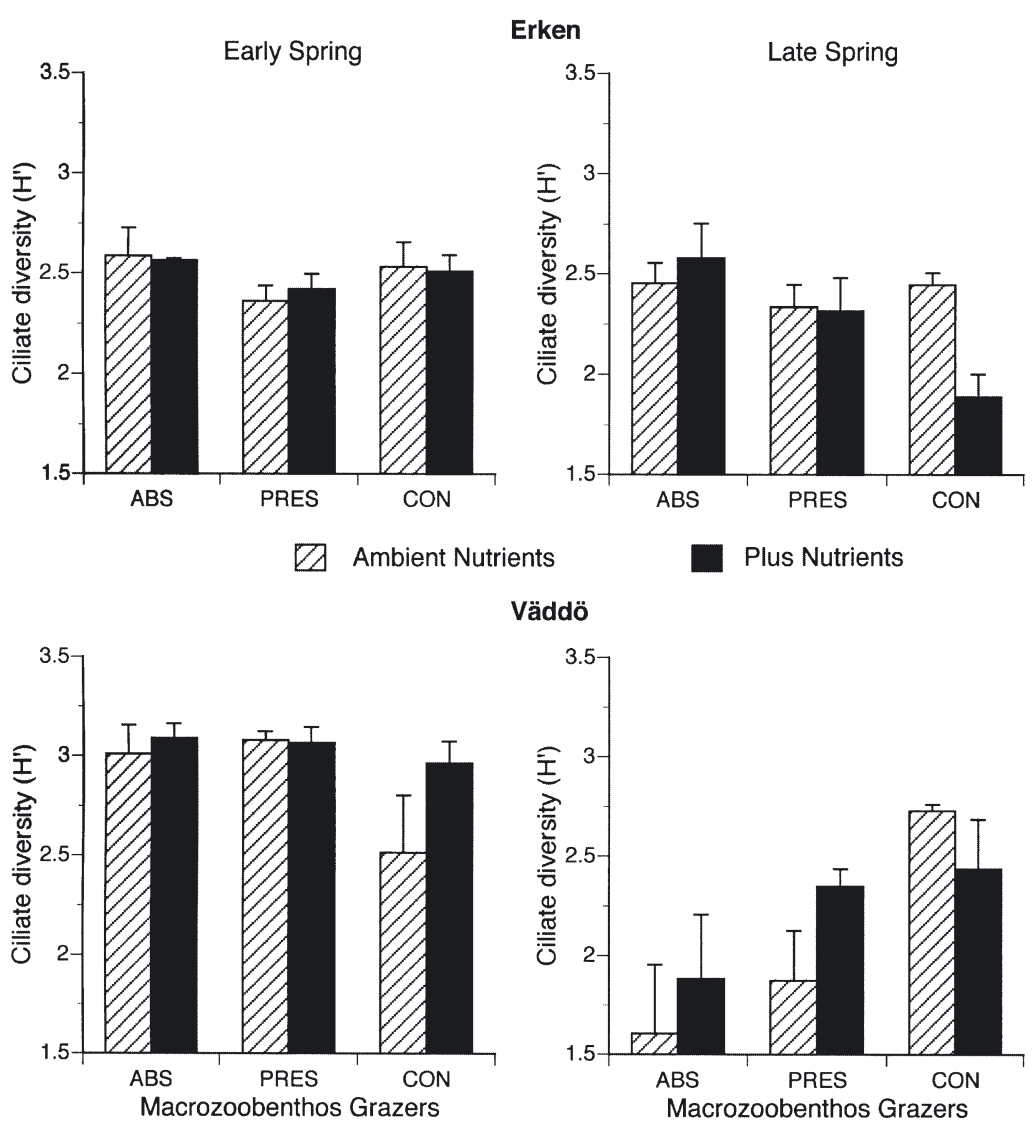

Väddö

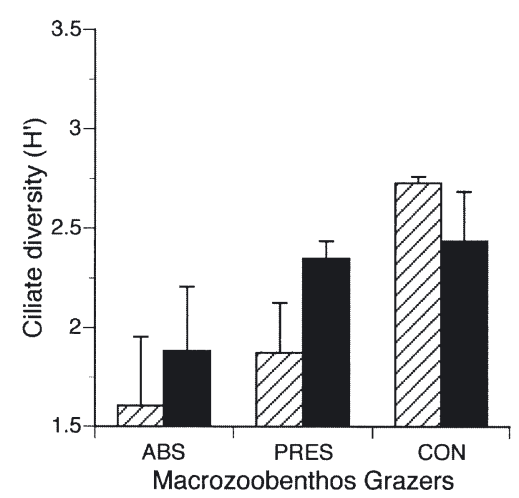

Fig. 4. Ciliate diversity in the 4 experiments, as calculated by the ShannonWiener diversity index, $\mathrm{H}^{\prime}$, using ciliate abundance and natural logarithms. Abbreviations, symbols and error bars as in Fig. 1 were present, but only under ambient nutrient conditions. This would suggest that competition with macrozoobenthos for shared algal resources was an important control factor for these ciliates. Macrozoobenthos had no effects on these groups when nutrients were added and algal biomass increased, consistent with a competition hypothesis.

The weak effect of nutrients on ciliate abundance and biomass was also unexpected, for 2 reasons. First, nutrient effects are known to influence macrozoobenthos grazers (Hart \& Robinson 1990, Worm et al. 2000). Ciliates have higher growth rates than macrozoobenthos, and would therefore be expected to react more quickly to increased resources. There were, however, positive correlations between ciliates and their bacterial and algal prey, indicating at least a weak coupling between ciliates and their resources. The length of the experiments (4 to $6 \mathrm{wk}$ ) was enough for any increase in ciliate biomass or abundance due to increased nutrients to be passed on to higher trophic levels, an effect seen for meiofauna and algae (Montagna et al. 1995). Ciliate growth rates may have indeed been higher with raised nutrient levels, but if mortality due to
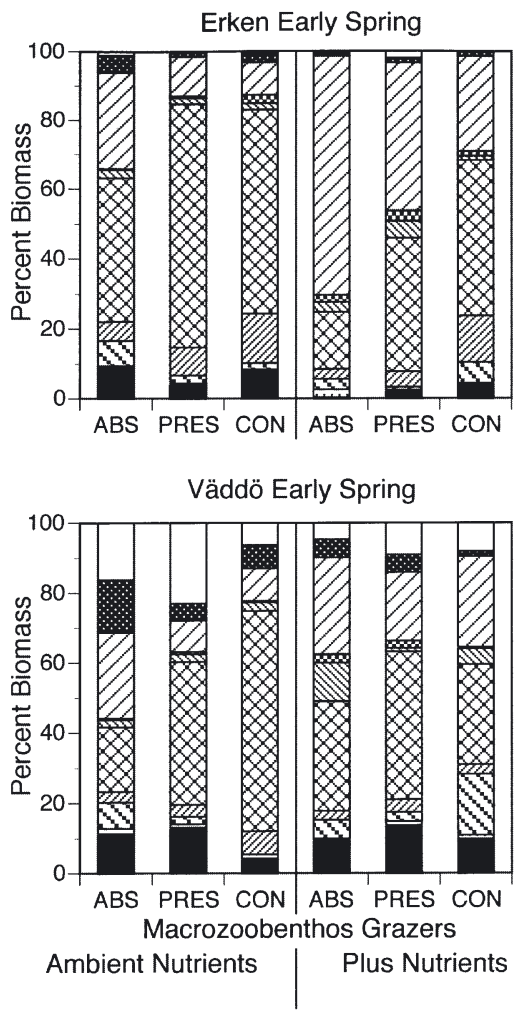
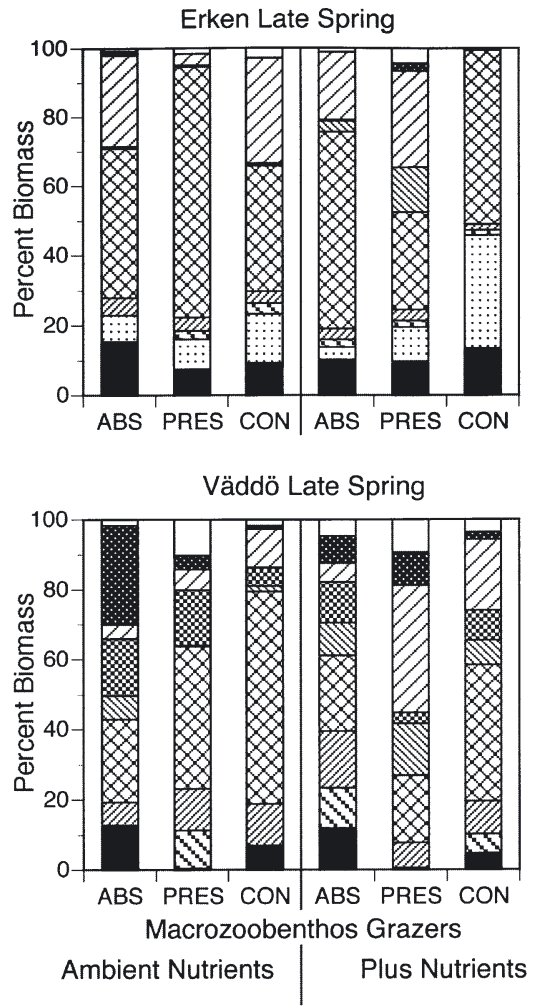

Fig. 5. Percent composition of the ciliate community in the 4 experiments. Total ciliate biomass was partitioned among the 9 most abundant taxa, at either the class or order level. The 10th group, 'Other', is composed of all groups that did not make up at least $2 \%$ of the total biomass at in any treatment in any experiment along with unidentified ciliates. As in Fig. 1, ABS, PRES and CON are the macrozoobenthos absent, macrozoobenthos present and the cage control treatments 
grazing also increased, then ciliate numbers would return to near non-nutrient addition levels. However, grazer effects were also generally more pronounced than nutrient effects for the algae in the experiments (Hillebrand \& Kahlert 2001) and stronger top-down than bottom up effects have also been found for infaunal communities, using a similar experimental design (Posey et al. 1999).

A second reason for a strong effect of nutrients is that algivorous ciliates (heterotrichs, nassiphorids, hypotrichs and stichotrichs) made up a substantial proportion of the total ciliate biomass (Fig. 5), and would be expected to profit from the increased periphyton biomass that accompanied the nutrient addition. This enhancement occurred to a limited degree, but was offset by a decline, particularly in the peritrichs, resulting in only a small increase in total biomass. Nutrient addition did not benefit all benthic algae equally, but increased the dominance of relatively large chainforming and filamentous species (Hillebrand 2003). The ciliate groups that could best graze these sorts or algae were the heterotrichs, due to their relatively large size, and the Phyllopharynia and nassulids (grouped with 'Other'), due to their oral apparatus. These groups did in fact increase in their relative contribution to total ciliate biomass when nutrients were added. This was most evident in the Erken early spring experiment (Fig. 5), but collectively across experiments, heterotrichs increased significantly in proportion, from 10 to $30 \%$ when nutrients were added (loglikelihood ratio test: $\mathrm{p}=0.0001$ ). A direct nutrient effect on ciliates was most easily seen when heterotrichs increased their proportion of ciliate biomass (Erken early spring and Väddö late spring experiments, Figs. $2 \& 5)$. The heterotrichs found in the experiments were relatively large species such as Stentor spp. and Climacostumum virens, which were found in low numbers. Nutrients having their greatest effect on a group of rare large species had 2 consequences: (1) the nutrient effect was seen for ciliate biomass, but not for abundance; and (2) there was relatively high variance in the biomass, even after the data were log-transformed. Finding one Stentor more or less had a much larger impact on the biomass of a replicate than on abundance. This explains the relatively high p-value for the grazer and nutrient effects on biomass, despite relatively large differences in the means between treatments.

The effect of the manipulations on ciliate diversity and species richness was remarkably weak (Figs. 3 \& 4). This was despite the ciliate communities being substantially different both between sites and experiments, with no more than $54 \%$ of the same morphotypes appearing in any 2 experiments (Table 2). Theoretical and experimental studies have shown changes in diversity with changing productivity and predation regimes, with intermediate grazing pressure and nutrient levels increasing benthic algal diversity (Paine \& Vadas 1969, Kassen et al. 2000, Sommer 2000, Worm et al. 2002). Either intermediate grazer densities or intermediate nutrient levels prevent a competitively dominant prey species from eliminating weaker competitors, while very high predation rates or very low productivity allow only the most resistant forms to survive (Paine 1966, Gaedeke \& Sommer 1986, Flöder \& Sommer 1999). Both ciliate diversity and species richness varied between seasons and sites, but neither the main effects or the interaction of grazers and nutrients produced even a nonsignificant trend. It may be argued that predator density was in all treatments low to moderate, and nutrients were always intermediate, and therefore no changes in diversity or species richness were to be expected. However, the experimental manipulations changed algal biomass in a range from nothing to nearly $100 \%$, dependent on the treatment and experiment (Hillebrand et al. 2002); a range that would seem sufficient to produce changes in ciliate diversity. The experimental manipulations were also strong enough to affect algal diversity, with additional nutrients decreasing and grazers increasing, evenness (Hillebrand 2003). It should be noted that the types of algae most affected by the experimental manipulations (filamentous and chain-forming species) were those least likely to be suitable ciliate prey, and the effects on the (for ciliates) more edible single cell forms was less (Hillebrand et al. 2002). Nevertheless, epibenthic ciliate diversity appears less sensitive to changes at higher or lower trophic levels than would be expected from work on other groups.

The results from these experiments make clear that while both nutrients and macrozoobenthos grazers may affect ciliates, simple direct effects are more the exception than the rule. The experiments also show that without good taxonomic resolution, the indirect effects which seemed to dominate in our experiments would be even more difficult to unravel. At least in comparison to meiofauna, ciliates make up a substantial proportion of the periphyton grazer community and can potentially play an important role. Determining their role in epibenthic communities can only be done though manipulative experiments, but, as with algae and other groups, with the best possible taxonomic resolution.

Acknowledgements. We thank Lars Peters and Ann-Louise Haglund for help in the field. The manuscript benefited from comments by Ulrike Berninger (who also contributed to the early stages of the experimental work), Tanja Burgmer and Monika Claeßens-Kenning as well as 2 anonymous reviewers. 


\section{LITERATURE CITED}

Abrams PA (1995) Monotonic or unimodal diversity-productivity gradients: What does competition theory predict? Ecology 76:2019-2027

Bott TL, Borchardt MA (1999) Grazing of protozoa, bacteria, and diatoms by meiofauna in lotic epibenthic communities. J N Am Benthol Soc 18:499-513

Bott TL, Kaplan LA (1990) Potential for protozoan grazing of bacteria in streambed sediments. J N Am Benthol Soc 9: 336-345

Carey PG (1992) Marine interstitial ciliates: an illustrated key. Chapman \& Hall, London

Epstein SS (1997) Microbial food webs in marine sediments. I. Trophic interactions and grazing rates in two tidal flat communities. Microb Ecol 34:188-198

Epstein SS, Gallagher ED (1992) Evidence for facilitation and inhibition of ciliate population growth by meiofauna and macrofauna on a temperate zone sandflat. J Exp Mar Biol Ecol 155:27-39

Fenchel T (1980) Relation between particle size selection and clearance in suspension-feeding ciliates. Limnol Oceanogr 25:733-738

Flöder S, Sommer U (1999) Diversity in planktonic communities: An experimental test of the intermediate disturbance hypothesis. Limnol Oceanogr 44:1114-1119

Foissner W, Berger H, Schaumburg J (1999) Identification and ecology of limnetic plankton ciliates, Vol 3/99. Informationsberichte des Bayerischen Landesamtes für Wasserwirtschaft, Munich

Frost PC, Elser JJ (2002) Growth responses of littoral mayflies to the phosphorus content of their food. Ecol Lett 5: $232-240$

Gaedeke A, Sommer U (1986) The influence of the frequency of periodic disturbances on the maintenance of phytoplankton diversity. Oecologia 71:25-28

Hart DD, Robinson CT (1990) Resource limitation in a stream community: phosphorus enrichment effects on periphyton and grazers. Ecology 71:1494-1502

Hill WR, Boston HL, Steinman AD (1992) Grazers and nutrients simultaneously limit lotic primary productivity. Can J Fish Aquat Sci 49:504-512

Hillebrand H (2003) Opposing effects of grazing and nutrients on diversity. Oikos 100:592-600

Hillebrand H, Kahlert M (2001) Effect of grazing and nutrient supply on periphyton biomass and nutrient stoichiometry in habitats of different productivity. Limnol Oceanogr 46:1881-1898

Hillebrand H, Kahlert M, Karlsson AL, Berninger UG, Nagel S, Wickham SA (2002) Control of microbenthic communities by grazing and resource supply. Ecology 83: 2205-2219

Kahl A (1930-1935) Urtiere oder Protozoa: I: Wimpertiere oder Ciliata (Infusoria), eine Bearbeitung der freilebenden und ectocomensalen Infusorien der Erde, unter Ausschluß der marinen Tintinnidae. In: Dahl F (ed) Die Tierwelt Deutchlands. Fischer Verlag, Jena, p 1-886

Kassen R, Buckling A, Bell G, Rainey PB (2000) Diversity peaks at intermediate productivity in a laboratory microcosm. Nature 406:508-512

Magurran AE (1988) Ecological diversity and its measure-

Editorial responsibility: John Dolan,

Villefranche-sur-Mer, France ment. Princeton University Press, Princeton, NJ

McCormick PV (1991) Lotic protistan herbivore selectivity and its potential impact on benthic algal assemblages. J N Am Benthol Soc 10:238-250

McCormick PV, Cairns JJ (1991) Effects of micrometazoa on the protistan assemblage of a littoral food web. Freshw Biol 26:111-119

Montagna PA, Blanchard GF, Dinet A (1995) Effect of production and biomass of intertidal microphytobenthos on meiofaunal grazing rates. J Exp Mar Biol Ecol 185:149-165

Montagnes DJS, Lynn DH (1987) A quantitative protargol stain (qps) for ciliates: method description and test of its quantitative nature. Mar Microb Food Webs 2:83-93

Paine RT (1966) Food web complexity and species diversity. Am Nat 100:65-75

Paine RT, Vadas RL (1969) The effects of grazing by sea urchins, Strongylocentrotus spp. on benthic algal populations. Limnol Oceanogr 14:710-719

Posey M, Alphin TD, Cahoon L, Lindquist D, Becker ME (1999) Interactive effects of nutrient additions and predation on infaunal communities. Estuaries 22:785-792

Putt M, Stoecker DK (1989) An experimentally determined carbon:volume ratio for marine "oligotrichous" ciliates from estuarine and coastal waters. Limnol Oceanogr 34: $1097-1103$

SAS Institute (1989) SAS/STAT Users Guide, Version 6, 4th edon, Vols 1 and 2. SAS Institute, Cary, NC

Schmid-Araya JM, Schmid PE (2000) Trophic relationships: integrating meiofauna into a realistic benthic food web. Freshw Biol 44:149-163

Šimek K, Vrba J, Hartman P (1994) Size-selective feeding by Cyclidium sp. on bacterioplankton and various sizes of cultured bacteria. FEMS Microb Ecol 14:157-168

Šimek K, Bobková J, Macek M, Nedoma J, Psenner R (1995) Ciliate grazing on picoplankton in a eutrophic reservoir during the summer phytoplankton maximum: a study at the species and community level. Limnol Oceanogr 40: $1077-1090$

Skibbe O (1994) An improved quantitative protargol stain for ciliates and other planktonic protists. Arch Hydrobiol 130: 339-347

Sokal RR, Rohlf FJ (1995) Biometry, 3rd edn. WH Freeman, New York

Sommer U (2000) Benthic microalgal diversity enhanced by spatial heterogeneity of grazing. Oecologia 122:284-287

Stelzer RS, Lamberti GA (2002) Ecological stoichiometry in running waters: periphyton chemical composition and snail growth. Ecology 83:1039-1051

Taylor WD (1980) Observations on the feeding and growth of the predacious oligochaete Chaetogaster langi on a ciliated protozoa. Trans Am Microsc Soc 99:360-368

Wickham SA, Gieseke A, Berninger UG (2000) Benthic ciliate identification and enumeration: an improved methodology and its application. Aquat Microb Ecol 22:79-91

Worm B, Lotze HK, Sommer U (2000) Coastal food web structure, carbon storage, and nitrogen retention regulated by consumer pressure and nutrient loading. Limnol Oceanogr 45:339-349

Worm B, Lotze HK, Hillebrand H, Sommer U (2002) Consumer versus resource control of species diversity and ecosystem functioning. Nature 417:848-851

Submitted: September 1, 2003; Accepted: January 12, 2004

Proofs received from author(s): April 22, 2004 